\title{
John Ogilvie: The Smoke and Mirrors of Confessional Politics
}

\author{
Allan I. Macinnes \\ University of Strathclyde \\ allan.macinnes@strath.ac.uk
}

\begin{abstract}
The trial and execution of the Jesuit John Ogilvie in 1615 is located within diverse political contexts-Reformation and Counter-Reformation; British state formation; and the contested control of the Scottish Kirk between episcopacy and Presbyterianism. The endeavors of James VI and I to promote his ius imperium by land and sea did not convert the union of the crowns into a parliamentary union. However, he pressed ahead with British policies to civilize frontiers, colonize overseas and engage in war and diplomacy. Integral to his desire not to be beholden to any foreign power was his promotion of religious uniformity which resulted in a Presbyterian backlash against episcopacy. At the same time, the Scottish bishops sought to present a united Protestant front by implementing penal laws against Roman Catholic priests and laity, which led to Ogilvie being charged with treason for upholding the spiritual supremacy of the papacy over King James. Ogilvie's martyrdom may stand in isolation, but it served to reinvigorate the Catholic mission to Scotland.
\end{abstract}

\section{Keywords}

British state formation - ius imperium - penal laws - recusancy - Presbyterians episcopacy - lingering Catholicism - treason

Constant harassment by the Protestant Kirk in the wake of the Reformation, reinforced by threats of civil sanctions against regular clergy, practicing Roman Catholics and those who aided them, certainly restricted the scope for

(C) ALLAN I. MACINNES, 2020 | DOI:10.1163/22141332-00701003

This is an open access article distributed under the terms of the prevailing CC-BY-NC-ND 4.0 license. 
Counter-Reformation in Scotland. Yet, there is limited evidence for the serious prosecution of clerical and lay Catholics in the later sixteenth century. Catholicism was a declining, if lingering force, its laity much given to compromising on matters of church attendance and partaking of communion as a Protestant sacrament: its practice outside of Edinburgh - which was possibly never without a mass despite the Reformation - tended to be confined to aristocratic households in town and country where occasional masses were held for families, friends and servants. In this context, perhaps only the Bog of Gight and Enzie within the Strathbogie district of Aberdeenshire were continuously served by priests protected by the Gordons, the Hays and the Ogilvies. Barely a handful of priests were active in Scotland by 1603 , when the union of the crowns coincided with the death in exile of the last of the pre-Reformation hierarchy, James Beaton (1524-1603), archbishop of Glasgow (1552-1603), ambassador for James VI (1566-1625 r. [Scotland] 1567-1625 [England ]1603-25) in France, and principal benefactor of the Scots College in Paris, whose work included the training of priests. ${ }^{1}$

Yet, the composite enactment of penal laws by the Scottish Parliament in 1609, which brought together legislation against Roman Catholics passed piecemeal since 1573, was undoubtedly draconian in tenor. Catholics, and those who aided and abetted them, were liable in the first instance to have their goods and gear confiscated if convicted. Catholics refusing to participate in Protestant communions were to be excommunicated and liable to have all rents and revenues sequestrated. Contumacious offenders ultimately faced charges of treason, and if convicted, capital punishment as well as outright forfeiture of their estates, if members of the landed classes. Although their reimposition was trumpeted intemperately, the enforcement of the penal laws was not comprehensive. ${ }^{2}$ John Ogilvie (1578/9-1615) was to prove the exception, however. Why this was so tells us as much about Protestant as well as Catholic confessional politics at a time when James VI of Scotland and I of England as attempting to promote the unification of Great Britain as an imperial project.

1 Margaret Sanderson, "Catholic Recusancy in Scotland in the Sixteenth Century," Innes Review 21, no. 2 (1970): 87-107; Anthony Ross, "Reformation and Repression," in Essays on the Scottish Reformation, 1513-1625, ed. David McRoberts (Glasgow: J. S. Burns \& Sons, 1962), 371-414; Narratives of Scottish Catholics under Mary Stuart and James VI, ed. William Forbes-Leith (Edinburgh: W. Paterson, 1885), 269-74.

2 Much of the material in this chapter on the political context for the penal laws is drawn from Allan Macinnes, "Catholic Recusancy and the Penal Laws, 1603-1707," Records of the Scottish Church History Society 23 (1987): 27-63. 
The prospect of a forced or negotiated union between the English Tudor and the Scottish Stewart dynasties had stimulated considerable debate on the topic of British state formation in the course of the sixteenth century. ${ }^{3}$ This wideranging debate, marked by a heady mixture of myth, humanism, and providentialism, was hugely influential in the determination of the new king of England and Scotland to be viewed from 1603 as James of Great Britain. His resolve to establish a new British dynasty under the Stuart appellation-based on the Francophile adaptation first patented by his mother, Mary Queen of Scots (1542-87; r.1542-67) — was complemented by his commitment to a British state that would harmonize differing English and Scottish perceptions about union. ${ }^{4}$

As a firm advocate that monarchy was divinely interposed between God and civil society, James viewed dynastic consolidation as the first step towards perfect union under an imperial monarchy. Dynastic union consolidated by political incorporation opened up the prospect of British leadership in a Protestant Europe battling to resist Anti-Christ in the form of the papacy and the whole panoply of the Counter-Reformation. This imperial vision of godly monarchy, enunciated initially in The True Lawe of Free Monarchies (1597) was followed up by Basilikon doron (1599), essentially a manifesto for his dynasty's divine right to succeed to the English throne. On the one hand, James drew demonstrably on traditional English claims to be an empire free from papal control. On the other hand, he rebutted Presbyterian claims to the autonomy of the Scottish Kirk, whereby government through bishops, the Erastian preference of imperial monarchy, faced replacement by an autonomous hierarchy of ecclesiastical courts. ${ }^{5}$

The fundamental reconfiguration of Britain was also a prime concern of the founder of Scottish Presbyterianism, Andrew Melville (1545-1622), humanist,

3 Roger Mason, Kingship and the Commonweal: Political Thought in Renaissance and Reformation Scotland (East Linton: Tuckwell, 1998), 242-69; Arthur Williamson, "Education, Culture and the Scottish Civic Tradition," in Shaping the Stuart World, 1603-1714: The American Connection, ed. Allan Macinnes and Arthur Williamson (Leiden: Brill, 2006), 33-54.

4 Allan Macinnes, The British Revolution, 1629-166o (Basingstoke: Palgrave Macmillan 2004), $8-39$.

5 James H. Burns, The True Law of Kingship: Concepts of Monarchy in Early Modern Scotland (Oxford: Clarendon Press, 1996), 54-92, 185-254; Jenny Wormald, "James VI and I, Basilikon doron and The Trew Law of Free Monarchies: The Scottish Context and the English Translation," in The Mental World of the Jacobean Court, ed. Linda Peck (Cambridge: Cambridge University Press, 1991), 36-54. 
educational reformer, and meddlesome academic. In a pastoral eulogy on the birth of Prince Henry (1594-1612), eldest son of James VI in 1594, Melville anticipated that the future regal union would join Scotland and England in a united commonwealth. This new commonwealth, however, was but the first step in a grand confederation of free Protestant states. David Hume of Godscroft (1558-1629), the leading Presbyterian intellectual in Jacobean Britain, was no less committed to full integration. In 1605 , he promoted a complete political and religious union that would lead to the fusion of British peoples. ${ }^{6}$ However, in moving the Protestant Kirk firmly in a Calvinist direction, Melville made no concessions to the Crown in the exercise of spiritual jurisdiction. The kirk and the state were to be distinctive but complementary agencies working to sustain a godly commonwealth. Although Presbyterianism became the established faith of Scotland in 1592, the autonomy of the kirk from the state was not conceded. The king retained the right to choose the time and place of general assemblies, which James used to good effect to bring back bishops by 1597, albeit in a limited capacity to represent the kirk in parliament. By 1606 , James had moved overtly onto the offensive against Melville and his Presbyterian associates who were subjected variously to detention in London, banishment from Scotland for life or internal exile in northern districts remote from the central belt. Bishops were restored to their temporal estates and, as part of the royal supremacy in kirk and state, given full spiritual powers in $1610 .{ }^{7}$

James viewed bishops as essential to his claims to exercise imperial power in Scotland as in England and Ireland. His Stuart dominions were subordinate to no spiritual or temporal power by land or sea, whether that was the papacy or the Holy Roman Emperor. Thus, the Authorised Version of the Bible produced under his imprimatur in 1611 endorsed his imperial vision of godly monarchy and his resolve that English should be the prescribed language of Reformed civility throughout his British dominions. The essentially Anglican character of religious uniformity was underscored. John Thornborough, bishop of Bristol (1551-1641), had welcomed the providential reunification of the British Empire under a godly monarch as an occasion of great happiness that would be perfected by the eventual merging of the constituent identities of England and

6 The British Union: A Critical Edition and Translation of David Hume of Godscroft's De unione Insulae Britannicae, ed. Paul McGinnis and Arthur Williamson (Aldershot: Ashgate, 2002), $1-53$.

7 John Spottiswood, The History of the Church of Scotland, 3 vols. (Edinburgh: Bannatyne Club, 1850-51), 3:157-64, 179-83, 194-95; John Row, The History of the Kirk of Scotland (Edinburgh: Wodrow Society, 1842), 227-49. 
Scotland into a composite British nation. ${ }^{8}$ James also sponsored the publication in Scotland of a work that allied providence and prophecy to his Britannic project. The claims of an anonymous English apologist that the miraculous and happy union between England and Scotland would prove expeditious and profitable to both nations, and stop unnecessary wars, were reprinted in Edinburgh in 1604. This endeavor to convince the Scottish Estates to participate, without equivocation, in the creation of "the moste opulent, strong and entire Empire of the worlde," capable of transatlantic confrontation with Spain and the papacy, was made redundant by the failure of the English Parliament to support political incorporation. ${ }^{9}$

Despite the rejection of political and commercial integration in 1607, James was determined to demonstrate the sovereign independence of the three kingdoms under imperial monarchy. Accordingly, he promoted an international British agenda as manifest in foreign policy through espionage, embassies and military intervention in the Thirty Years' War, a policy continued by his son Charles I (160o-49; r.1625-49) on his accession in 1625. At the same time, the early Stuarts' Britannic version of ius imperium gave territorial as well as ideological integrity to the unity of Scotland, England and Ireland as multiplekingdoms; a perspective which also sought to demonstrate the interdependence of the three kingdoms at home and abroad. Thus, James implemented civilizing projects designed to bring order throughout his exclusive Britannic Empire-namely, the cross-Border policing of the Middle Shires, the plantation of Ulster, and the military and legislative offensive against the West Highlands and Islands. The annexation of Orkney and Shetland was partly an extension of such a frontier policy, but primarily the consolidation of the territorial waters around the British Isles into the Stuarts' ius imperium. His projection of the Stuarts as the first composite British dynasty impacted significantly on colonial policy. While trading and colonial ventures were authorized separately from Scotland and England, the Britannic perception of empire was particularly suited to their endeavors to challenge, by acquisition and settlement, Spanish dominion in the New World. ${ }^{10}$

8 John Thornborough, Bishop of Bristol, A Discourse Shewing the Great Happiness that hath and may still accrue to his Majesties Kingdomes of England and Scotland By re-Uniting them into ane Great Britain (London, 1604).

9 Anon., The Miraculous and Happie Union of England \& Scotland (Edinburgh, 1604).

10 Glenn Burgess, The Politics of the Ancient Constitution: An Introduction to English Political Thought, 1603-1641 (University Park, PA: Macmillan, 1992), 129-30; Arthur Williamson, "Scots, Indians and Empire: The Scottish Politics of Civilization, 1519-16o9," Past \& Present 150 (1996): 46-83; Steve Murdoch, Britain, Denmark-Norway and the House of Stuart, 1603-166o (East Linton: Tuckwell, 2000), 44-63. 
The imperial standing of King James in all three kingdoms of Scotland, England, and Ireland was reinforced by the internationalism of his Britannic perspective. James elevated Great Britain into the premier league of international diplomacy. He was instrumental in establishing the political accord that prevented the territorial dismemberment of Russia to suit the respective interests of Sweden, Poland, and the English Muscovy Company prior to the accession of the Romanov dynasty in 1613. His sponsorship of international Synods at Tonneins in 1614 and at Dort in 1618-19 marked him out as the undisputed leader of the Reformed or Calvinist tradition and a creditable promoter of a united Protestant front of Calvinists and Lutherans against Spanish and Austrian Habsburg hegemony in tandem with the Counter-Reformation in Europe. ${ }^{11}$

But amidst this smoke of imperial ambition, key events in British unification are mirrored in the actions authorized by James against Catholics leading up to the trial of John Ogilvie. The penal laws against Roman Catholics were partially re-enacted in 1604 following the departure of the court south from Edinburgh to London and at the commencement of negotiations for an incorporating union between commissioners for the Scottish Estates and the English Parliament. At the same time, James was sponsoring the publication of supportive prophecy in favor of union. Partial re-enactment was repeated in 1607 on the rejection of the king's scheme for a complete and closer union. The codification and collation of the penal laws in 1609 was directed towards stilling Presbyterian unease about the re-insinuation of episcopacy into the kirk. Ogilvie's trial and execution in 1615 came in the midst of James promoting and projecting himself as leader of the Reformed tradition.

\section{Catholicism and the Penal Laws in Scotland, 1603-25}

His queen, Anna (1574-1619), having converted to Catholicism before their departure to England, James was personally tolerant towards the leading Catholic nobles despite their covert diplomatic dealings with France, Spain, and the papacy before 1603. Nevertheless, his arrival in England had led to the regular application of fines, sufficient to stifle the development of Catholicism and to ensure that leading Catholics were made to feel uncomfortable, but never

11 Lori Anne Ferrell, Government by Polemic: James I, the King's Preachers, and the Rhetorics of Conformity, 1603-1625 (Stanford, CA: Stanford University Press, 1998), 113-39; Paul Bushkovitch and Maija Jansson, "Introduction," in England and the North: The Russian Embassy of 1613-1614, ed. Maija Jansson, Paul Bushkovitch, and Nikolai Rogozhin (Philadelphia: American Philosophical Society, 1994), 47-71. 
desperate, far less rebellious. Despite its fleeting appearance during 1607, ostensibly as a confederacy of Catholic gentry, the "Society of Boyis" was not so much a militant political lobby as a territorial grouping of kinsmen and local associates to uphold Gordon hegemony in the north-east. ${ }^{12}$ Forbearance continued to be the key to the king's disciplining of leading Catholics. George Gordon, sixth earl (later first marquess) of Huntly (1561/2-1636) and Francis Hay, ninth earl of Errol (c.1564-1631), were imprisoned respectively in Stirling and Dumbarton Castles. They were liberated at the outset of 1611 on the understanding that they would restrict their movements to their estates pending remedial religious instruction. Full freedom of movement was restored to both in 1613. Although a handful of Catholic gentry had moveable goods confiscated and were forced temporarily into exile overseas, no attempt was made to forfeit them. Indeed, considerable parliamentary opposition was evident at the codification and collation of the penal laws in 1609 to a proposal that bishops should submit annual lists of Catholics excommunicated as recusants to the exchequer and chancery. This proposal, which would have made land transfers conditional on clerical testimonials, was rendered inoperable though formally enacted. ${ }^{13}$

However, the Scottish bishops were determined to demonstrate forcibly their leadership of the Kirk, following on from the parliamentary ratification of the full restitution of episcopal authority in 1612. A markedly vindictive phase in the application of the penal laws was characterized by comprehensive judicial commissions and the instigation of treasonable proceedings against Catholic clergy and laity. The judicial commissions empowered bishops to take the initiative in searching out Catholic clergy and laity and those that harbored and protected them. They were also empowered to stamp out practices redolent of lingering Catholicism; notably, perennial pilgrimages to chapels, wells and crosses, and the seasonal observance of festival days, carol singing, bonfires and guising. The most intemperate episcopal prosecutor was John Spottiswood (1565-1639), then archbishop of Glasgow (later translated to St. Andrews), who had served notice of his anti-Catholic zeal in 1609 by breaking in to the house of the aged Gilbert Brown (d.1612), last abbot of Newabbey, in order to remove books, sacramental artefacts, icons and vestments for public burning in the high street of Dumfries. A prior attempt to secure his arrest by a contingent of

12 Robert Pitcairn, Ancient Criminal Trials in Scotland, 3 vols. (Edinburgh: Maitland Club, 1833), 2:532-35; Gordon Donaldson, Scotland: James V to James VII (Edinburgh: Mercat Press, 1965), 188-94, 216, 220.

13 John J. La Rocca, "James I and his Catholic Subjects, 1606-1612: Some Financial Implications," Recusant History 18 (1987): 251-62. 
royal guards on his return from banishment in 1608 had led to an armed riot by sympathizers drawn to the town from Nithsdale and Galloway. ${ }^{14}$

The trial and conviction of James Stewart, alias James of Jerusalem, as the principal resetter of priests in Edinburgh, heralded a more vigorous approach to the containment of Roman Catholicism under episcopal direction in November 1613. Although sentenced to perpetual banishment, this far-travelled cadet of the Ochiltree family from Ayrshire was not obliged to leave the country for another eighteen months. The restoration of the bishops also led to a return to the situation pre-Reformation when leading clerics became career civil servants; most notably Spottiswood, who contrived unity among Protestants by enforcing the penal laws against Roman Catholics. ${ }^{15} \mathrm{His}$ principal target was a Jesuit priest captured while walking in Glasgow after working clandestinely in Edinburgh and Renfrewshire as well as in his native north-east. After three months of exhaustive questioning unrelieved by torture, mainly in the form of protracted sleep deprivation, John Ogilvie was tried for treason in Glasgow in February 1615. Ogilvie was convicted less for his Jesuit ministry than for his uncompromising stance in upholding the spiritual supremacy of the papacy over James VI and I ${ }^{16}$ whose conversion to Roman Catholicism the Jesuits had long prioritized. Indeed, the Jesuit mission in Scotland from the later sixteenth century was politically driven - to win over the king and his nobility. ${ }^{17}$ In turn, Ogilvie's execution sent a clear political message. Melvilleans no less than Catholics were warned about the perils of denying the royal supremacy in kirk and state.

Three more priests over the next eleven years faced execution, but their sentences were commuted into banishment from Scotland for life. Robert Moffat was apprehended in St. Andrews around the time Ogilvie was being detained in Glasgow and was likewise tortured prior to conviction. He was sentenced to perpetual banishment rather than capital punishment for his purportedly treasonable activities as a priest after throwing himself on the mercy of the

14 Malcolm V. Hay, The Blairs Papers 1603-166o (London: Sands \& Co., 1929), 187, 242.

15 John Durkan, "Sidelights on the Early Jesuit Mission in Scotland," Scottish Tradition 13 (1984-85): 34-45; David Calderwood, The History of the Kirk of Scotland, 8 vols. (Edinburgh: Wodrow Society, 1842-49), 7:193-97, 202; Forbes-Leith, Narratives of Scottish Catholics, 296-313.

16 William J. Anderson, "A Jesuit That Calls Himself Ogilvie," Innes Review 15, no. 1 (1964): 56-65; Pitcairn, Ancient Criminal Trials, 3:252-57, 330-54.

17 Michael J. Yellowlees, "So strange a monster as a Jesuite": The Society of Jesus in Sixteenth Century Scotland (Colonsay: House of Lochar, 2003), 2-3, 34-5, 42, 157-59, 191; Thomas M. McCoog, "Pray to the Lord of the harvest': Jesuit Missions to Scotland in the Sixteenth Century," Innes Review 53, no. 2 (2002): 127-88. 
specially constituted court in October 1615. Two months earlier, Moffat's three main resetters in Edinburgh were threatened with torture and actually sentenced to death following charges of treason. They were only saved from the gallows by a last-minute reprieve from the royal court which commuted their capital punishment into perpetual banishment overseas for William Sinclair, advocate and Robert Wilkie, embroiderer. Robert Cruikshank, stabler, was ordered to quit Edinburgh. Charges of treason were also brought against the three principal resetters of John Ogilvie in and around Glasgow. But their trial, which commenced in September 1615, was adjourned for four months and then terminated. The accused were obliged to give financial sureties for their future conduct: Sir James Clelland of Monkland was bound over for ten thousand merks ( $£ 6,667$ Scots), William Maxwell of Cowglen for five thousand merks $\left(£_{3,333)}\right)$ and Robert Urie, writer in Paisley for five thousand merks $\left(£_{333}\right)$. Two Jesuit priests, Patrick Anderson (1574/5-1624) and James Macbreck, faced capital punishment in 1620 and 1626 respectively. They were spared but banished, partly because they were less uncompromising than Ogilvie when faced by their examiners and partly because they refrained from claiming to be engaged in a large missionary endeavor in Scotland. Macbreck also had influential connections at the French court who were able to bring diplomatic pressure on Charles I in the course of his betrothal and marriage to Princess Henrietta Maria. ${ }^{18}$

The penal laws were reissued and amplified in 1616 to bring prosecutions within the scope of Courts of High Commission, creations of the royal prerogative rather than statute and dominated by the bishops. The reissue also signaled the commencement of James VI and I's liturgical program, which emerged as the Five Articles of Perth at the general assembly of the kirk in 1618. By far the most controversial of these innovations was the requirement that all partakers of communion had to kneel before the bishop or minister when receiving the sacrament, a measure that reeked of a return to the preReformation role of priests as intermediaries between God and man. Reissue was again designed to still Presbyterian unease about the royal direction of the kirk through a compliant episcopate who were increasingly coming under the influence of William Laud (1573-1645), bishop of London, an opponent of Calvinism who viewed Protestantism in Scotland not so much as Reformation as deformation. He had begun his episcopal career at St David's in Wales, which was still a major center for pilgrimage. There was no systematic renewal of

18 John Durkan, "Miscellany Notes on Jesuits," Innes Review 21, no. 2 (1970): 153-61; Memoirs of Scottish Catholics during the $17^{\text {th }}$ and $18^{\text {th }}$ Centuries, ed. William Forbes-Leith, 2 vols. (London, 1909), 1:21, 361-62; Pitcairn, Ancient Criminal Trials, 3:371-78. 
treasonable prosecutions of Catholic clergy and laity. A few Catholic gentry indicted as recusants were given the option of conforming or quitting Scotland for an indefinite period. Those who opted for exile but subsequently returned without license after several years of banishment were admonished. Swinging fines were not imposed. Their moveable goods were not confiscated, or their rents and revenues sequestrated. ${ }^{19}$

The final proclamation re-imposing the penal laws during the reign of King James was issued in 1624, in response to Protestant apprehensions about the king's well-publicized endeavors to match his heir, Prince Charles, with the Spanish Infanta. These apprehensions were aggravated by unconfirmed reports of a general toleration for Catholics throughout the British Isles and were intensified by Presbyterian claims that a private conference of Scottish bishops and selected ministers at St. Andrews in April 1623 was to seek a measured accommodation between the kirk and the papacy. Re-imposition of the penal laws also gave the impression that the king was even-handed in his dealings with nonconformists, whether Catholic recusants or Presbyterians refusing to accept the Five Articles of Perth as ratified by the Scottish estates in 1621 . In practice, punitive sanctions were largely restricted to conventiclers, the vanguard of nonconforming Presbyterians particularly prominent among the mercantile communities in Edinburgh and Glasgow. ${ }^{20}$

\section{Catholicism in Scotland after John Ogilvie's Execution}

Far from presaging wholesale prosecutions leading to the extinction of all deemed recusants, the trial and execution of John Ogilvie, from Strathisla in Banffshire, reinvigorated Catholicism in the Lowlands. The missionary ground rules, which were recalibrated from 1617 by the Jesuits, remained elitist but political considerations were tempered by greater weighting for liturgical usages and catechizing. Especially targeted were landed families, particularly those with heritable jurisdictions able to protect priests and encourage conversions within their territorial spheres of influence. Leading Catholic families were encouraged to intermarry, both to consolidate their faith and bridge their

19 Row, History of the Kirk of Scotland, 302, 306-7; Calderwood, History of the Kirk of Scotland, 7:222-27, 488, 514-15; Allan Macinnes, Charles I and the Making of the Covenanting Movement, 1625-1641 (Edinburgh: John Donald, 1991), 155-58.

20 David Stevenson, "Conventicles in the Kirk, 1619-37: The Emergence of a Radical Party," Records of the Scottish Church History Society 18 (1972-74): 99-114; Calderwood, History of the Kirk of Scotland, 7:507-8, 514-15, 558, 565, 571-72, 6oo-27. 
geographical isolation. From 1622, with the exception of the Jesuits, oversight of all regular and secular clergy on the Scottish Mission was exercised spiritually, if not always financially, by the Sacred College of Propaganda at Rome. The Jesuits, however, remained reluctant to co-operate with other missionaries, particularly the secular clergy: not just because their order had pioneered and continued to bear the brunt of missionary work, but because the secular clergy were perceptively less well equipped intellectually, administratively, and materially to endure a life of personal privation and constant movement to spread the faith. ${ }^{21}$

Chronic underfunding by Propaganda and missionary rivalries notwithstanding, Catholicism thrived within geographic pockets, most notable in the north-east within the territorial bounds of the house of Huntly, Scotland's premier Catholic family, and among the kinsmen and associates of the Maxwell earls of Nithsdale and lords Herries in the south-west. Catholicism also sustained a peripheral presence in the households of nobles and gentry in Tayside, the Lothians and west-central Scotland. The state's underwriting of the compulsory powers of the kirk to direct the education of Catholic children, to remove them from parental control during schooling into the care of their nearest Protestant relations and to subject parents to remedial religious instruction did occasion families to be reconciled to Protestantism. Nonetheless, lingering Catholic practices continued to survive in the Lowlands from Dumfries and Galloway to Perthshire on to Aberdeenshire, Moray and the Black Isle well into the eighteenth century. Despite their condemnation by Presbyterians as superstitious or more malevolently as witchcraft, people continued to visit wells for their reputed healing powers for humans and livestock. Most such "physic wells" have a firm religious connection being located near chapels dedicated to saints or the Holy Family, as did annual fairs in rural and even some urban localities. Moreover, the practice of pilgrimage had not been entirely eradicated. ${ }^{22}$

In the Highlands and Islands, the relative neglect of organized religion, allied to widespread spiritual deprivation since the Reformation, had offered the greatest prospects for the entrenchment of Catholicism as the faith of whole

21 Forbes-Leith, Memoirs of Scottish Catholics, 1:1-40; Hay, The Blairs Papers, 52-221; Peter F. Anson, Underground Catholicism in Scotland 1622-1878 (Montrose: Standard Press, 1970), $8-17,47-56,60-77,85-87$.

22 Geographical Collections relating to Scotland Made by Walter Macfarlane, ed. Arthur Mitchell, 3 vols. (Edinburgh: Scottish History Society, 1906-8), 1:11, 15, 22, 25, 30, 34, 36-37, 49, 51, 56, 70, 80, 100, 102-3, 105, 108, 132, 207, 235, 238, 255, 392; 2:59, 65, 70, 87, 94, 97, 214; 3:91, 213 . 
communities. The strenuous efforts of Jesuits and secular priests to maintain a minimal presence in the Highlands from the outset of the seventeenth century did lead to marginal inroads among communities bordering the Lowlands, notably in Perthshire and the north-east, where chiefs and gentry who formed the clan elite and factors for Lowland landlords tended to be bilingual. ${ }^{23}$ Because of the dearth of native Gaelic speakers, the main impetus for the work of conversion throughout the Highlands and Islands was provided by Irish priests, especially the Franciscans from 1619. Unlike the Lowlands, Catholicism within the Highlands and Islands can be identified not just with landed households but with clans such as the MacNeils in Barra and the MacDonalds of Clanranald in Moidart, Eigg, Canna, South Uist, and Benbecula. However, optimistic accounting in the course of the Irish missions cannot be dissociated from their desperate need to attract funding from Propaganda. The Highlands and Islands, no less than the Lowlands were in direct competition for finite missionary resources with vastly more fertile areas for conversion in the Far East, Asia Minor and the Americas. With only a handful of priests serving in the Highlands and Islands, conversions did not always last beyond initial missions in Kintyre and the Inner Hebrides, in Ardnamurchan, Sunart and Glenelg, and in Caithness and Sutherland. ${ }^{24}$

Nevertheless, lingering Catholicism was evident not only in pilgrimages, visits to wells and chapels, which still thrived in the Highlands and Islands in the mid-seventeenth century, but also in hymns and incantations which can be traced back to the Celtic church in the early middle ages. As recorded in the second half of the nineteenth century, drawing on oral traditions from Episcopalians as well as Catholics, religion infused the whole fabric of life with blessings for everyday use by the laity. In addition to prayers to saints and the Holy Family, there were prayers against ill reports; at dressing and rising; before confession; for grace, protection, cattle, seaweed, travelling, and victory; and of baptism, distress and protection. ${ }^{25}$ Historical dating from internal evidence

23 James Kirk, "The Jacobean Church in the Highlands, 1567-1625," in The Seventeenth Century in the Highlands, ed. Loraine Maclean (Inverness: Inverness Field Club, 1981), 24-51; John Durkan, "William Murdoch and the Early Jesuit Mission in Scotland," Innes Review 35, no. 1 (1984): $3^{-11 .}$

24 The Franciscan Mission to Scotland, 1619-46, ed. Cathaldus Giblin (Dublin: Assisi Press, 1964), passim; Giblin, “The 'Acta' of Propaganda Archives and the Scottish Mission, 16231670," Innes Review 5, no. 1 (1954): 39-76; John Lorne Campbell, "The MacNeils of Barra and the Irish Franciscans," Innes Review 5, no. 1 (1954): 33-38.

25 Mitchell, Geographical Collections, 2:154, 172, 187; Alexander Carmichael, Carmina Gadelica: Hymns and Incantations Collected in the Highlands and Islands of Scotland (Edinburgh, 1972), passim. 
covers the mid-fourteenth to the mid-eighteenth century and includes contemporaries of John Ogilvie, such as John MacDonald of Moidart (c.1600-70), chief of the Clanranald, who wrote a celebrated letter to the papacy in 1626 offering to launch a military campaign to bring Scotland back to "the true apostolic Roman faith." This proposed Clanranald crusade, eleven years after the martyrdom of Ogilvie, was less a realistic project for Counter-Reformation than a despairing effort to secure gainful employment for clansmen denied livings as mercenaries following the plantation of Ulster. No less pertinently, MacDonald of Moidart was opportunely attempting to secure international mediation for his repeated failure to account to the Scottish government in Edinburgh for the conduct of himself as his clansmen; a requirement introduced in 1609 and reinforced in 1616 carrying the prospect of heavy fining and even forfeiture for recidivists. ${ }^{26}$

26 John Lorne Campbell, "The Letter Sent by Iain Muideartach, Twelfth Chief of Clanranald, to Pope Urban VIII, in 1626," Innes Review 4, no. 2 (1953): 110-16; Allan Macinnes, Clanship, Commerce and the House of Stuart, 1603-1788 (East Linton: Tuckwell, 1996), 72-79. 